Marquette University

e-Publications@Marquette

$1-1-2014$

Pluralism and Anti-Pluralism in Economics: The Atomistic Individual and Religious Fundamentalism

John B. Davis

Marquette University, john.davis@marquette.edu

This is an Accepted Manuscript of an article published by Taylor \& Francis in Review of Political Economy, Vol. 26, No. 4 (2014): 495-502, available online: https://www.tandfonline.com/doi/abs/ 10.1080/09538259.2014.950459. (c) 2014 Taylor \& Francis (Routledge). Used with permission. 


\section{Pluralism and anti-pluralism in economics: The atomistic individual and religious fundamentalism*}

John Davis, Marquette University and University of Amsterdam

Abstract: This short paper examines a possible connection between religion and economics in terms of the parallelism between the atomistic individual doctrine and the individual soul doctrine. The paper explores whether resistance to pluralism in economics as a methodological practice might be illuminated in terms of this connection. On this view, resistance to pluralism in economics is not a matter of economists holding methodological views about economics practice that are contrary to pluralism, but is rather a kind of anti-pluralism reflecting an intransigent defense of the atomistic individual view as a kind of core or 'untouchable' deep doctrine. Two arguments are advanced to demonstrate the parallelism between the atomistic individual doctrine and the individual soul doctrine.

Keywords: pluralism in economics, atomistic individual, religion and economics, fundamentalism

JEL classification: Z12, B41, B2

\footnotetext{
* Thanks go to Dave Colander, Amitava Dutt, Zohreh Emami, Wade Hands, Gary Mongiovi, a referee of this journal, and those at the November 11-13, 2011 Third triennial research conference of the International Confederation of Associations for Pluralism in Economics for helpful comments on a previous version of this paper.
} 
Two students came up to me once at a conference in Europe at which pluralism in economics had been discussed, and said they believed people in the United States were quite religious, and asked was this possibly a reason why economists in the US were so strongly attached to standard economic theory? Basically they were trying to tie something they understood broadly as a religious fundamentalism to something on the order of an economic fundamentalism, and thought that if there was a connection, this meant that pluralism in economics was not likely to find fertile soil in the US. I replied that I hadn't thought about the idea, and that I was skeptical that such an argument could be made in a persuasive way. If they meant that the views of American economists were to be explained by their being religious, then the view was too simple and likely wrong. I also thought there might be many reasons for what could be called an economic fundamentalism in the US, including a widely held commitment among many American economists to a neoliberal view of the world. But the question of a link between US economics and religion stuck with me. Subsequently I found that Robert Nelson (Nelson, 2001; see also Perlman, 2003) had been similarly provoked by the relationship between economics and religion in the US, and so I ultimately asked myself how this issue could conceivably be addressed. This brief comment is the result of that reflection. To begin, I asked myself why there was indeed so little support for pluralism in economics in the US, and then made a distinction between the nature and status of pluralism in economics.

\section{$2 \quad$ Pluralism vs. anti-pluralism in economics}

What is the nature and status of pluralism in economics? Its nature is not much disputed: it is widely agreed to be a methodological value that it is often believed ought to govern economists' practice vis-àvis approaches to the subject matter of economics rival to their own, specifically, economists ought to adopt a position of open-mindedness toward approaches different from their own. Its status, however, is more difficult to explain. Most heterodox economists would say that mainstream economics is not pluralistic. But what does this mean? If we go by the nature of pluralism as stated above, this suggests that many economists do not share this particular methodological value, and do not believe that they ought to adopt a position of open-mindedness toward approaches different than their own. In effect, they have different methodological values that govern their practice. For example, perhaps they believe 
that economics advances through a competition between approaches, and that they should dedicate themselves to the strongest defense of approaches they think best.

This interpretation may have some truth to it, but in my view it produces an incomplete understanding of the status of pluralism in economics in the US. The problem with making this a matter of economists having different methodological values is that this implies that the status of pluralism in economics a matter of normative dispute over how economics ought to be practiced. But at the same time we seldom see any debate or discussion over methodological values in economics. Thus something else seems to motivate most American economists in this regard, and absent any other apparent basis for their position, I suggest that there must be certain underlying forces operating in mainstream economics that constitute inherent barriers to pluralist practice. On this view, pluralism does not operate in any significant way in economics not because there are differences between economists regarding methodological values; pluralism does not operate in any significant way in economics because of certain forces operating in economics that push methodological debate to the side altogether. That is, the opposite of pluralism in economics is not the methodological goal of dedicated defense of one's own explanation to give it the best hearing possible as suggested above, but rather an anti-pluralism driven by forces underlying much contemporary economic theorizing that exclude reasonable debate over what methods of analysis are admissable.

Suppose, then, that anti-pluralism seen as a force operating in economics has two characteristics. First, it involves intransigent opposition to openness based on the need to defend specific deep conceptual structures which is disconnected from all reasonable debate over their coherence and epistemic value. These 'untouchables,' as I will call them, are always defended, in one form or another, no matter what might be argued about them or what happens to the rest of the theory in which they operate. Imre Lakatos (1970) believe something like untouchable conceptual structures existed as the hard core of most scientific theories, though he did not seek to explain why they exist. Second, the meaning of these untouchable conceptual structures might be said to have a two-tier character: their surface meanings are shaped by the theories in which they operate, but they also possess further underlying meanings to which these surface meanings are related. These underlying meanings generally go unrecognized, so that conceptual elaboration is confined to the surface meanings, the defense of which, however, is motivated by attachment to their underlying meanings. The attachment to these underlying meanings makes their proponents' intransigent opposition to openness a matter of a force operating within 
science rather than an epistemic concern, and thus makes their opposition to others' views an antipluralism rather than a disagreement over methodological values.

\section{The atomistic individual as a domain of surface meaning}

Is this two-tier meaning view plausible? The test of the view, it seems fair to say, rests with whether it can be applied to examples of intransigence over specific conceptual structures in economics. Of course what counts as intransigence can be debated, but in any event I nominate one particular conceptual structure in economics as an example par excellence of where I believe many economists will accept very little compromise or modification of basic assumptions involved, and which indeed for many arguably constitutes the lynch pin of standard theory: the atomistic individual concept. The basic assumptions I refer to are what I characterized as surface meanings, which are assumptions shaped by the theories in which they operate. At this level, economists who disagree in many ways, for example, such as neoclassical and behavioral economists who differ over the nature of motivation and how markets work, may still share a single set of basic assumptions that define the atomistic individual. In this section I describe these basic surface assumptions, and in the next section then describe the further underlying assumptions to which I believe these surface assumptions are linked, and which therefore on the argument here would justify characterizing the proponents of the atomistic individual doctrine as anti-pluralist.

The atomistic individual idea is that people are essentially autonomous. This means that though what they do may be influenced by others (as in game theory) and by what goes on in economic life (how prices and incomes constrain their choices), ultimately their actions stem from them alone. This view has as its most common statement the idea that a person's preferences are exogenous. It is an odd view, because everyone - including proponents of the doctrine - knows that people's preferences are influenced by many things. Despite this, the standard view is that why people come to have the preferences they do is irrelevant to the explanation of choice which takes them as given in the act of choice. It is true, of course, that one can explain choice with given preferences without saying anything about the formation of those preferences. Their formation and the person's acting upon them are two different things. But if we know preferences are susceptible to being influenced, why would we think this is a good explanation of choice? Why shouldn't how preferences are formed be central to our 
explanations of the choices people make? The answer, I suggest, is that one would only think the standard view is a good explanation of choice if one was already convinced that people's actions must ultimately stem from them alone and that people are essentially autonomous.

To better understand this commitment to autonomy, we should note what the specific grounds are in standard theory for the idea that people are essentially autonomous. Thus, autonomy is justified by saying that individuals have their own separate utility functions (whatever might be the origins of their preferences). The basis for this claim is the von Neumann-Morgenstern utility function theorem (von Neumann and Morgenstern, 1944), which says that if a specific set of logical assumptions regarding preferences is satisfied (completeness, transitivity, independence, and continuity), the individual has a well-defined preference ordering, which can be represented by a distinct (monotonic) individual utility function. That is, the well-orderedness of preferences implies personal autonomy (and vice versa). Needless to say, there has been much experimental research in recent years that casts doubt on whether this set of logical assumptions can be said to apply to people's preferences. ${ }^{2}$ But it seems another question should have been raised first regarding the 'own separate utility function' basis for personal autonomy. That is, why should one even think a logical derivation of autonomy constitutes a sound basis for ascribing autonomy to people? Since the deductive inference of the individual utility functions effectively generates autonomy by assumption, this axiomatic approach to autonomy only affirms what people have decided they wish to believe. ${ }^{3}$ Thus the recourse to a logical derivation of the atomistic individual basically serves the purpose of putting debate over how we should understand individuals off the table.

The subsequent development of the theory of rational choice further reinforces the autonomy-by-fiat approach. For example, despite their continued use of the utility function concept, most economists who use standard modeling use revealed preference theory to explain choice, and this allows them to deny that individual psychology has any relevance to the theory of choice (e.g., Gul and Pesendorfer, 2008). Revealed preference theory can be interpreted as claiming that choice reveals preferences, and thereby provides what economists believe to be an objective grounding for the idea that preference grounds the theory of demand. This justifies dropping any substantive reference to preference and

\footnotetext{
2 Thus it is not clear whether behavioral economics shares the atomistic individual doctrine, an issue I put aside here to focus on standard neoclassical theory, though see my view on this in Davis (2011).

${ }^{3}$ Or perhaps what their models of agents as atomistic require of them.
} 
personal psychology from the analysis of choice. It thereby compels us to say that choice is always autonomous choice, since nothing regarding how people might come to have the preferences they have can enter into its explanation. Choice is thus defined as the product of an autonomous individual. Note that the original justification for revealed preference theory was that individual psychology is unobservable, while one can observe people's choices (Samuelson, 1938). But what counts as observable and unobservable can be subject to debate. Revealed preference theory puts off this debate by simply denying that human psychology, or for that matter anything, might condition choice. The atomistic individual, then, is necessarily an autonomous being. ${ }^{4}$

Consider for a moment, however, what might be involved in thinking about individuals were one not to insist on their irreducible autonomy. To say that individual behavior is not fully autonomous is to say that individuals' choices are influenced by economic and social circumstances, and thus that individual behavior is in some manner endogenous to those circumstances. Of course economists reflect all the time upon what counts as exogenous and endogenous in developing economic models, and say that we should treat as exogenous those factors that influence but are not influenced by factors endogenously determined in their models. But this always raises the question of whether a model's exogenous factors might indeed be influenced by factors endogenous to that model, and so it is fair to say that an important part of the history of model development in economics involves continually probing what counts as exogenous in the pursuit of ever more comprehensive accounts of systems of determination in economic life. In the face of this, it is surely odd that so many mainstream economists have remained for over a century unwilling to investigate the exogeneity of individual preferences, the basis for treating the individual as an autonomous being. Why this is so, I will now argue, is that the atomistic individual is foundational to their anti-pluralism. This is to say that these economists' position is not one rooted in reasoned debate over the merits of different approaches in economics, but is driven by forces associated with unhesitating commitment to the further underlying meanings that are attached to the surface meanings of the atomistic individual idea discussed above. In the next section I spell out what underlying meanings may lie behind the surface meanings of the doctrine, and associate them with a similar deep commitment, namely, religious fundamentalism.

\footnotetext{
${ }^{4}$ For a fuller argument see Sen (1973) where it is argued that revealed preference theory assumes what it aims to provide (that is, the axioms of choice). Thus it reflects but does not support the view that preferences are exogenous and people are autonomous atomistic agents.
} 


\section{$4 \quad$ Religious fundamentalism and the underlying meaning of the atomistic individual idea}

What do I mean by religious fundamentalism? To be clear, I do not intend one popular meaning of fundamentalism, namely, conservative religious movements that often emphasize the literal interpretation of religious texts. Rather by the term religious fundamentalism I refer to what counts as fundamental doctrine in most monotheistic religions in virtue of what is essential to the nature of that type of religious belief. For example, it is fundamental to most monotheistic religions to say that the natural world must somehow be explained by its relation to God. Or, it is fundamental to most to say that God exceeds human understanding, and that faith is central to religious belief. There are indeed many dimensions of religious fundamentalism understood in this way, but the discussion here addresses only one of them, albeit one which is widely shared across religions that are otherwise quite different. This is the doctrine of the individual human soul. It is a doctrine that is fundamental, because it stands as a central if not indispensable component in the explanation of the relationship between human life and a transcendent God (at least in monotheism). Accordingly it is a doctrine which generally cannot be given up without at the same time giving up the religious commitment with which it is associated. Consider, then, two main aspects of the individual human soul doctrine.

First, human souls are essentially individual. A person's relationship to God, as manifest in having a soul, is fully individual. This is so strongly believed that it seems nonsensical to say, for example, that two people could share a human soul (putting aside metaphorical speech). But that idea is neither nonsensical nor logically contradictory; it is simply incompatible with the doctrine of the human soul as found in most religions which assign each individual one soul. Second, and this is especially important, there is only one thing that has a fundamental influence on or is a determinant of the well-being of the individual human soul, namely, its relation to God. Thus neither other people's souls nor anything in the natural world can interfere with or otherwise condition the relationship between an individual soul and God.

I want to argue, then, that economists' anti-pluralism regarding the atomist agent concept is analogous to religious fundamentalism regarding the individual soul. The argument makes two points: (a) that the atomistic individual doctrine operates as an untouchable conceptual structure in economics, and (b) that it does so because it possesses the same features as religious doctrines that are analogous in form. 
Then though the surface meanings of atomistic individual doctrine are specific to economics, its being an 'untouchable' in economics is due to its being treated as a fundamental, an underlying meaning associated with doctrines that are fundamental in other domains, such as the human soul doctrine. Thus, I do not argue that the atomistic individual doctrine is actually derived from the human soul doctrine, or even that it stems from a similar psychological impulse, but rather that the two doctrines are structurally analogous.

Consider simply the parallels or structural similarities between the atomistic individual doctrine and the human soul doctrine. In the human soul doctrine the individual is essentially autonomous; similarly in the atomistic individual doctrine the individual is essentially autonomous. Further, in the human soul doctrine nothing in the natural world can limit the individuality of the human soul; similarly in the atomistic individual doctrine nothing in human psychology or social interaction can limit a person's essential individuality. Thus the two doctrines are homeomorphic or have the same structures. But while the human soul doctrine is rooted in the idea that people have an exclusive individual relationship to God, there is no evident reason from the perspective of ordinary reasoning about modeling practices in economics to think that the pattern of preferences that define an agent's individuality are exogenous. Thus it is not implausible to say, based on the structural similarity of the two doctrines that the surface meaning of the atomistic individual doctrine employs a kind of human soul doctrine as its deeper meaning.

This argument, of course, does not prove that religious fundamentalism and the human soul doctrine provide the underlying meaning of the atomistic individual doctrine. Indeed I remain skeptical that arguments stronger than the suggestive ones above can be made. At the same time, they point to an issue that it seems ought to be addressed, namely, that the logical character of the atomistic individual doctrine bears a strong resemblance to religious argument in how they both follow out the implications of a basic set of assumptions, and that this is not in keeping with standard procedures for theoretical advance in science, including much of economics, which sets aside purely logical argument and tests the empirical standing of basic assumptions. At the very least, then, the arguments here are an invitation to proponents of the atomistic individual doctrine to explain their grounds for supposing individuals are essentially autonomous. That this explanation is likely not forthcoming, however, seems to confirm its role as an 'untouchable' in economics. 
My starting point in this discussion was the lack of support for pluralism in economics. Indeed most economists do not even see pluralism in economics as an issue, if they recognize the idea at all. This is compatible with their simply having a different view of methodological practice in economics, such as the idea that one ought to allow the competition between different approaches (in the 'marketplace of ideas') determine which ideas prevail. Against this interpretation, however, is the fact that economists nonetheless do practice a kind of 'pluralism' - if not in name - then institutionally speaking with respect to specialization across and within economic fields. It is 'pluralist' in a way, and involves a kind of openmindedness, because economics departments do not expect specializations, say, industrial organization and monetary economics, to compete with one another, and generally accept that there are different legitimate research programs in different fields. Further, not only is 'pluralism' in this sense firmly institutionalized in economics as a methodological practice, but that practice is based on principles of cooperation and not competition. But this creates a puzzle. Why is the discourse of pluralism itself so absent from economics? My answer concerns the role of the 'untouchables' in economics.

One aspect of an institutionalized 'pluralism' built around specialization, then, is that it leaves much about the specialization to the specialist acting as a monopolist on the condition that the specialist and specialization are seen as having certain broadly acceptable features, such a set of conceptual constructs that are shared across fields. Thus every specialization possesses a domain of non-interference but also possesses certain shared entry points. My contention, thus, is that this combination promotes an intransigence regarding these shared constructs, since they are the means by which fields secure their domains of non-interference. An institutionalized 'pluralism' by fields, that is, ironically depends upon a rejection of pluralism regarding shared conceptual constructs which could well then have the effect of discouraging general pluralist discourse. In effect, the price of private 'pluralism' is public anti-pluralism.

This sort of explanation raises the question of why particular conceptual constructs become pivotal in sustaining private 'pluralism' and public anti-pluralism. This paper provides an explanation of how the atomistic individual doctrine could be thought to fulfill this pivotal shared construct role by explaining it as fundamentalist. The case for this fundamentalism rests on the parallel structures and functionalities of the atomistic individual doctrine and the individual soul doctrine, which clearly has the status of a fundamental doctrine in monotheistic religion. The argument was not, it should again be emphasized, that the atomistic individual doctrine is actually derived from the human soul doctrine. Rather as a 
shared construct in economics that operates as an 'untouchable' it must have the same characteristics as other doctrines that have this status. The human soul doctrine is a premier model in this regard, and consequently what makes it fundamental in religion provides guidelines for the underlying meaning of the atomistic individual doctrine that must be retained in its surface meanings.

Thus the atomistic individual doctrine appears to work quite like a kind of religious fundamentalism. This still leaves unaddressed the two European students' question about US economists, religion, and pluralism. After all, specialization in economics and mainstream doctrines exist elsewhere as well. But they do seem to have been right on the mark in asking about the foundations of intolerance and what has been called here anti-pluralism.

\section{References}

Davis, J. (2011) Individuals and Identity in Economics (Cambridge, UK: Cambridge University Press).

Gul, F. and Pesendorfer, W. (2008) The Case for Mindless Economics, in: A. Caplin \& A. Schotter (Eds.) The Foundations of Positive and Normative Economics: A Handbook, pp. 3-39 (Oxford: Oxford University Press).

Lakatos, I. (1970) Falsification and the Methodology of Scientific Research Programmes, in: I. Lakatos \& A. Musgrave (Eds.) Criticism and the Growth of Knowledge, pp. 91-196 (Cambridge, UK: Cambridge University Press).

Nelson, Robert (2001) Economics as Religion: From Samuelson to Chicago and Beyond, University Park, PA: Penn State University.

Neumann, J. von, and Morgenstern, O. (1944) Theory of Games and Economic Behavior, second edition 1947, third edition 1953 (Princeton, NJ, Princeton University Press).

Perlman, Mark (2003) "Robert H. Nelson on Romanism, Protestantism and American Economics: a review essay," Review of Political Economy 15 (2): 245-55.

Samuelson, P. (1938) A Note on the Pure theory of Consumer Behavior, Economica, 5, pp. 61-71. 
Sen, A. (1973) Behaviour and the Concept of Preference, Economica, 40, pp. 241-259. 